\title{
Prophylactic cranial irradiation in non-small cell lung cancer patients: who might be the candidates?
}

This article was published in the following Dove Press journal:

Cancer Management and Research

16 August 2011

Number of times this article has been viewed

\author{
Charalampos \\ Dimitropoulos' \\ Georgios Hillas ${ }^{2}$ \\ Sofia Nikolakopoulou ${ }^{2}$ \\ loanna Kostara ${ }^{2}$ \\ Konstantinos Sagris ${ }^{2}$ \\ Fotis Vlastos ${ }^{2,3}$ \\ Manos Alchanatis ${ }^{3}$ \\ '9th Respiratory Medicine \\ Department; ${ }^{2}$ Department \\ of Respiratory and Critical Care \\ Medicine, Research Unit; ${ }^{3}$ University \\ of Athens, Ist Respiratory Medicine \\ Department, University of Athens \\ Medical School, "Sotiria" Chest \\ Diseases Hospital, Athens, Greece
}

Correspondence: Georgios Hillas

152 Mesogeion Avenue,

11527 Athens, Greece

Tel +302107763566

Fax $+306937415725,+302107473969$

Email ghillas70@yahoo.gr
Objectives: Brain metastases (BMs) often advance the course of non-small cell lung cancer (NSCLC). We performed an observational study in order to investigate the possible correlation of selected clinical and epidemiological factors with BM appearance in patients suffering from different histological subtypes of NSCLC stage I-IV.

Methods: The study included 161 consecutive patients with NSCLC. Analyzed data included patient- and tumor-related characteristics.

Results: Thirty-nine patients $(24.2 \%)$ presented BMs within $12(0-36)$ weeks of diagnosis. BMs decreased the mean overall survival significantly (15.6 versus 50.7 weeks, $P<0.001$ ), with hazard ratio (95\% confidence interval) 3.60 (2.42-5.35). The age of the patients with BM was significantly lower than that of the patients without BM $(60.8 \pm 8.9$ versus $66.5 \pm 8.5$, $P<0.001)$. Patients with BM had significantly higher pack-years consumption $(75.9 \pm 23.9$ versus $58.9 \pm 31.9, P=0.003$ ) and larger tumor size compared with patients without $\mathrm{BM}$ (size in $\mathrm{mm}$ : $55.1 \pm 20.1$ versus 45.9 $\pm 19.3, P=0.012)$. The presence of BM was also correlated with the absence of lung $(P<0.001)$, bone $(P=0.005)$, and adrenal $(P=0.046)$ metastases.

Conclusion: Younger NSCLC patients with high tobacco consumption, large tumor size, and absence of metastases in other organs (lung, bones, adrenal metastases) are at high risk of BM appearance during the course of NSCLC and are candidates for prophylactic cranial irradiation early in the course of the disease.

Keywords: NSCLC, brain metastases, clinical and epidemiological factors, PCI

\section{Introduction}

Lung cancer was the leading cause of death from cancer in Europe in 2006, with 334,800 deaths (19.7\% of total). ${ }^{1}$ Non-small cell lung cancer (NSCLC) is the most common type of lung cancer, representing more than $80 \%$ of lung cancer cases. ${ }^{2}$

Brain metastases (BMs) are a frequent complication of NSCLC, especially in patients with locally advanced disease. ${ }^{3,4}$ The addition of chemotherapy to radiation therapy (RT) reduces distant metastases and significantly improves survival. ${ }^{5,6}$ However, chemoradiotherapy is shown not to reduce the rate of $\mathrm{BM},{ }^{5}$ but to be associated with increased rates of overall brain failure $(21 \%-54 \%)$ and an increased incidence of the brain as the first site of relapse $(15 \%-30 \%) .^{5-8}$ These findings emphasize the need for treatment specifically directed at brain micrometastases.

Prophylactic cranial irradiation (PCI) has been demonstrated to reduce the incidence or delay the onset of BM in patients with locally advanced NSCLC, after initial treatment in numerous selected nonrandomized and randomized studies. ${ }^{3,7,9-16}$ Nevertheless, during the last decade only few studies assessed the clinical and 
epidemiological factors associated with high risk of BM appearance in NSCLC patients with locally advanced disease at diagnosis. ${ }^{14,17-20}$ In these studies, several factors such as duration of survival after diagnosis, performance status, chemotherapy regimens, age at diagnosis, sex, and lung cancer histotype and stage have been associated with the risk of BM development.

The authors of this paper hypothesized that among NSCLC patients of stage I-IV may exist a group of patients at high risk of presenting BM that may be protected using PCI. This group should be identified in order to serve as target for future studies of PCI application in NSCLC.

We performed an observational study in order to investigate the possible correlation of selected clinical and epidemiological factors with BM appearance in patients suffering from different histological subtypes of NSCLC stage I-IV.

\section{Methods}

\section{The study's cohort}

We recruited 161 consecutive patients with a new diagnosis of NSCLC, between January 2003 and March 2009. Patients' selection criteria were as follows: confirmed diagnosis of NSCLC and appropriate staging. The sixth edition of the tumor-node-metastasis (TNM) classification was used. ${ }^{21}$

All patients were treated with surgery and/or chemotherapy and/or radiotherapy according to the current guidelines. ${ }^{22,23}$ They were evaluated every 3-6 months, depending on the curative or palliative nature of the initial treatment.

For each patient, the following variables were recorded at the time of diagnosis: age, sex, tobacco consumption, comorbidities, TNM status at diagnosis, tumor histotype, computed tomography (CT) scan features (central/peripheral location, side, lung lobe, size, cavitation, pleural effusion), and bronchoscopic findings. During the study period, the variables of patients with BM were registered and compared with those of patients without BM. All patients gave their informed consent, and the study was approved by the Ethics Committee of the "Sotiria" Chest Diseases Hospital, Athens.

\section{Statistical analysis}

Mean values (and standard deviation [SD]) or median values (and interquartile range [IR]) were used to describe quantitative variables. For the comparison of quantitative variables without normal distribution between two groups, and between three or more different groups, the MannWhitney test and Kruskal-Wallis test were used, respectively. To compare normal distributed quantitative variables between two groups and between three or more different groups, Student's $t$-test and analysis of variance test were used, respectively.

To control for type I errors, due to multiple comparisons, Bonferroni correction was used, by which the significance level is defined as $0.05 / k$ ( $k=$ number of comparisons). Logistic regression analysis (stepwise method) was used in order to find independent factors associated with BM presentation. Odds ratios (ORs) and $95 \%$ confidence intervals (CIs) were computed from the results of logistic analysis. Kaplan-Meyer method was used to estimate survival curves. To compare survival curves, log rank tests were used. Statistical significance was set at 0.05 , and all $P$-values are two tailed. For the statistical analysis, SPSS Statistics 17.0 (IBM Corporation, Somers, NY) and STATA 9.0 (Stata Corp, College Station, TX) programs were used.

\section{Results}

\section{Description of the cohort}

Patient's characteristics are summarized in Table 1. Most of the patients were males $(88.8 \%)$, with mean age $( \pm S D)$ $65.1 \pm 8.9$ years and mean tobacco consumption $( \pm \mathrm{SD})$ of $63.0 \pm 31.0$ pack-years.

Most of the tumors were located centrally (85.7\%). Therefore, they were located within the range of fiber bronchoscopy, which revealed mainly mucosal or submucosal infiltration (67.7\%). Most of the tumors were on the right lung $(52.2 \%)$ and on the upper lobes $(70.2 \%)$. The mean size $( \pm \mathrm{SD})$ of the tumors, measured on CT scanners, was $48.1 \pm 19.8 \mathrm{~mm}$. Almost one-third (36.6\%) were accompanied by pleural effusion at presentation. During the disease course, $37.3 \%$ of the patients presented lung, $36.6 \%$ bone, $23 \%$ liver, and $21.7 \%$ adrenal metastases.

\section{BMs}

BMs were presented in $24.2 \%$ of the patients. The median time (IR) of BM appearance was 12 (0-36) weeks from diagnosis. At the time of BM presentation, most of the patients were classified as T4 (42.9\%) and N2 (43.5\%) by the TNM classification. A total of $59 \%$ of the BMs were $\geq 2$, mostly unilateral (53.8\%).

The overall survival of the cohort was influenced by the presence of BM (Figure 1). Survival time of the patients with BM was shorter compared with those without BM: 15.6 weeks (standard error $[\mathrm{SE}]=1.9$ ) versus 50.7 weeks $(\mathrm{SE}=4.8, P<0.001)$. The hazard ratio, upon Cox model, for the presence of BM was 3.60 (95\% CI 2.42-5.35, $P<0.001)$. 
Table I Patient- and disease-related characteristics

\begin{tabular}{|c|c|}
\hline Characteristic & n (\%) \\
\hline \multicolumn{2}{|c|}{ Patient-related variables } \\
\hline \multicolumn{2}{|l|}{ Sex } \\
\hline Male/female & I43 (88.8)//8 (I I.2) \\
\hline \multicolumn{2}{|l|}{ Age } \\
\hline Mean \pm SD & $65.1 \pm 8.9$ \\
\hline \multicolumn{2}{|l|}{ Pack-years } \\
\hline Mean \pm SD & $63.0 \pm 31.0$ \\
\hline \multicolumn{2}{|l|}{ COPD } \\
\hline No/yes & $89(55.3) / 72(44.7)$ \\
\hline \multicolumn{2}{|l|}{ Arterial hypertension } \\
\hline No/yes & $98(60.9) / 63(39.1)$ \\
\hline \multicolumn{2}{|l|}{ Coronary disease } \\
\hline No/yes & I $32(82.0) / 29(\mid 8.0)$ \\
\hline \multicolumn{2}{|l|}{ Diabetes mellitus } \\
\hline No/yes & $136(84.5) / 25(15.5)$ \\
\hline \multicolumn{2}{|l|}{ Gastritis/ulcer } \\
\hline No/yes & I $38(85.7) / 23(14.3)$ \\
\hline \multicolumn{2}{|l|}{ Hypothyroidism } \\
\hline No/yes & $154(95.7) / 7(4.3)$ \\
\hline \multicolumn{2}{|l|}{ Other comorbidity } \\
\hline No/yes & I $30(80.7) / 3$ | (I9.3) \\
\hline \multicolumn{2}{|c|}{ Disease-related variables } \\
\hline \multicolumn{2}{|c|}{ Histotype } \\
\hline Non-differentiated & $49(30.4)$ \\
\hline \multicolumn{2}{|l|}{ NSCLC } \\
\hline Squamous & $49(30.4)$ \\
\hline Adenocarcinoma & $59(36.6)$ \\
\hline Large cell carcinoma & $4(2.6)$ \\
\hline \multicolumn{2}{|l|}{ Location } \\
\hline Central/peripheral & I $38(85.7) / 23(14.3)$ \\
\hline \multicolumn{2}{|c|}{ Bronchoscopic findings } \\
\hline Mass & $36(22.4)$ \\
\hline Infiltration & $109(67.7)$ \\
\hline None & $16(9.9)$ \\
\hline \multicolumn{2}{|l|}{ Lung tumor side } \\
\hline Right/left & $84(52.2) / 77$ (47.8) \\
\hline \multicolumn{2}{|l|}{ Lung tumor lobe } \\
\hline Upper & II $3(70.2)$ \\
\hline Middle & $8(5.0)$ \\
\hline Inferior & $40(24.8)$ \\
\hline Lung tumor size & \\
\hline Mean \pm SD & $48.1 \pm 19.8$ \\
\hline Other tumor & \\
\hline characteristics & \\
\hline Pleural effusion & $59(36.6)$ \\
\hline Cavitation & $12(7.5)$ \\
\hline None & $90(55.9)$ \\
\hline $\mathrm{T}$ classification & \\
\hline (brain metastases) $^{\mathrm{a}}$ & \\
\hline $\mathrm{T}_{1} / \mathrm{T}_{2}$ & $13(8.1) / 55(34.2)$ \\
\hline $\mathrm{T}_{3} / \mathrm{T}_{4}^{2}$ & $24(14.9) / 69(42.9)$ \\
\hline $\mathrm{N}^{3}$ classification & \\
\hline (brain metastases) $^{\mathrm{a}}$ & \\
\hline $\mathrm{N}_{0} / \mathrm{N}_{1}$ & $38(23.6) / 16$ (9.9) \\
\hline $\mathrm{N}_{2} / \mathrm{N}_{3}$ & $70(43.5) / 37(23.0)$ \\
\hline Lung metastasis & \\
\hline No/yes & $101(62.7) / 60(37.3)$ \\
\hline Bones metastasis & \\
\hline No/yes & $102(63.4) / 59(36.6)$ \\
\hline
\end{tabular}

(Continued)
Table I (Continued)

\begin{tabular}{|c|c|}
\hline Characteristic & n (\%) \\
\hline \multicolumn{2}{|l|}{ Liver metastasis } \\
\hline Nolyes & $124(77.0) / 37(23.0)$ \\
\hline \multicolumn{2}{|l|}{ Adrenal metastasis } \\
\hline Nolyes & $126(78.3) / 35(21.7)$ \\
\hline \multicolumn{2}{|l|}{ Other metastasis } \\
\hline No/yes & I44 (89.4)/I7 (10.6) \\
\hline \multicolumn{2}{|l|}{ Metastasis brain } \\
\hline Nolyes & I $22(75.8) / 39(24.2)$ \\
\hline \multicolumn{2}{|l|}{ Diagnosis to brain } \\
\hline \multicolumn{2}{|c|}{ metastases time (weeks) } \\
\hline Median (IR) & $12(0-36)$ \\
\hline \multicolumn{2}{|l|}{ Number of brain } \\
\hline \multicolumn{2}{|l|}{ metastases } \\
\hline $0 / 1$ & $122(75.8) / 16(9.9)$ \\
\hline $2 />2$ & $6(3.7) / 17(10.6)$ \\
\hline \multicolumn{2}{|c|}{ Brain metastasis side } \\
\hline Right & $12(30.8)$ \\
\hline Left & $9(23.0)$ \\
\hline Bilateral & $18(46.2)$ \\
\hline \multicolumn{2}{|c|}{ Brain metastasis lobe } \\
\hline Frontal & $9(23.1)$ \\
\hline Parietal & $9(23.1)$ \\
\hline Occipital & I (2.6) \\
\hline Cerebellum & $2(5.1)$ \\
\hline$\geq 2$ & $18(46.2)$ \\
\hline
\end{tabular}

The age of patients with BM was significantly lower compared with that of the patients without BM $(60.8 \pm 8.9$ versus $66.5 \pm 8.5, P<0.001$ ) (Table 2). Furthermore, patients with BM had significantly higher pack-years consumption $(75.9 \pm 23.9$ versus $58.9 \pm 31.9, P=0.003)$ and larger tumor size compared with patients without BM (size in $\mathrm{mm}: 55.1 \pm 20.1$ versus $45.9 \pm 19.3, P=0.012$ ). The presence of BM was also correlated with the absence of lung $(P<0.001)$, bone $(P=0.005)$, and adrenal $(P=0.046)$ metastases.

Patients with right-sided BM presented a significantly lower rate of arterial hypertension (16.7\% versus $83.8 \%$, $P=0.050$ ) (Table 3). None of the patients with unilobar BM suffered from diabetes, compared with patients with multilobar ( $\geq 2$ lobes) metastases $(P=0.015)$ (Table 4$)$.

According to regression analysis, age, tobacco consumption in pack-years, and absence of lung or bone metastases represented independent prognostic factors for the appearance of BM (Table 5). In particular, an increase of age reduced the possibility of BM appearance (OR 0.91; 95\% CI 0.87-0.96, $P<0.001)$. Conversely, increasing cigarette consumption increased the possibility of $\mathrm{BM}$ appearance (OR $1.02 ; 95 \%$ CI 1.001-1.030, $P=0.006)$. Patients without lung 


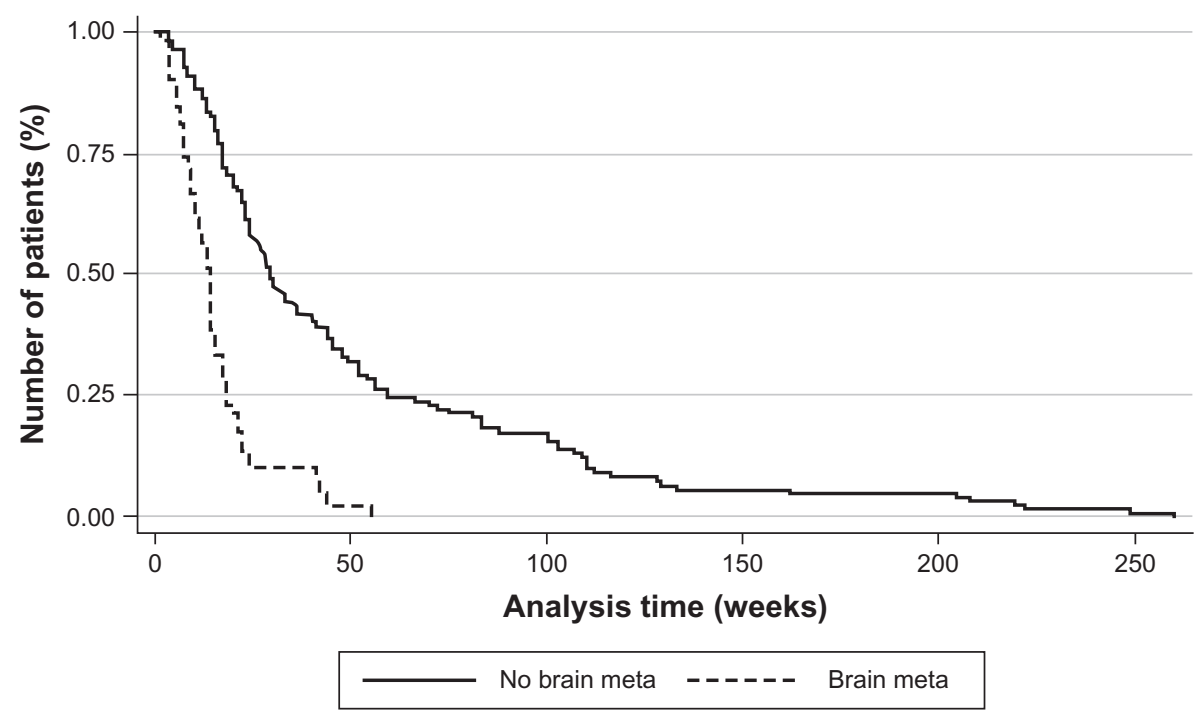

Figure I Kaplan-Meier estimation of overall survival (patients with or without brain metastases).

Abbreviation: meta, metastasis.

and bone metastases had $76 \%$ and $70 \%$ higher possibility of presenting BM, respectively.

\section{Discussion}

The main finding of this observational study was that younger NSCLC patients with high tobacco consumption, large tumor size, and absence of other metastases are at high risk of developing BMs during the course of their disease.

\section{BM appearance and survival}

Robnett et al reported that the timing of chest irradiation can influence the risk of brain recurrences: the rate of BM is $27 \%$ in patients receiving induction chemotherapy before thoracic RT compared with $15 \%$ in patients who are treated with concurrent chemoradiation. ${ }^{17}$ The 2-year actuarial rate of $\mathrm{BM}$ is $39 \%$ versus $20 \%$. The authors hypothesize that early aggressive locoregional and systemic treatment could better control regional disease, which in turn affects the development of brain relapses. In accordance with these findings, BMs presented in 39 out of 161 patients $(24.2 \%)$ in this present study. The rate of BM is quite similar to the rate which has been previously reported by Robnett et al for patients who were not treated with concurrent chemoradiotherapy. The lack of a radiotherapy department in the "Sotiria" Chest Diseases Hospital renders impossible the application of concurrent chemoradiotherapy and therefore leads to the application of the sequential module.

Once diagnosed, BMs are mostly treated with wholebrain radiotherapy, having a response rate of $45 \%-81 \%$ in NSCLC. ${ }^{24,25}$ The overall survival of NSCLC patients with
$\mathrm{BM}$ is poor, reported to be 3-6 months, despite medical treatment. ${ }^{26}$ The overall survival of the patients in this present study with BM was also poor, approximately 4 months.

\section{Patients who are at high risk of developing BM}

The delay of BM appearance is expected to improve prognosis of NSCLC patients. To achieve this, we need objective means to indicate patients at high risk for developing BM. Some studies have already been oriented towards this direction. Biologic agents like neuron specific enolase, carcinoembryonic antigen, serum sodium levels, or numerous molecular markers have been correlated with the development of BM and a shorter survival. ${ }^{26-28}$

Nevertheless, specific phenotypic characteristics may also serve as surrogate prognostic factors. Earlier studies correlated the presence of BM with advanced stage, NSCLC histotypes, delay of lung radiotherapy, younger age, and large tumor size. ${ }^{28-32}$ However, few studies assessed in this regard tobacco consumption, comorbidities, CT scanner tumor characteristics, or the presence of metastases other than BMs.

\section{Age at diagnosis}

Age $<60$ years was shown to be associated with an increased risk of BM. ${ }^{30,33,34}$ In this present study, younger age (60.8 \pm 8.9 years) was correlated with a higher possibility of BM appearance (Table 2). However, younger patients with BM present a better performance status and longer survival, while they may tolerate aggressive treatment better and are willing to accept a higher risk of toxicity than older patients. ${ }^{26,35}$ 
Table 2 Correlation of brain metastases with patient- and disease-related features (univariate analysis)

\begin{tabular}{|c|c|c|c|}
\hline \multirow[t]{2}{*}{ Feature } & \multicolumn{2}{|c|}{ Brain metastases } & \multirow[t]{2}{*}{$P \chi^{2}$ test } \\
\hline & No (N) & Yes (N) & \\
\hline \multicolumn{4}{|l|}{ Patient-related variables } \\
\hline \multicolumn{4}{|l|}{ Sex } \\
\hline Male/female & $108 / 14$ & $35 / 4$ & 0.833 \\
\hline \multicolumn{4}{|l|}{ Age } \\
\hline Mean \pm SD & $66.5 \pm 8.5$ & $60.8 \pm 8.9$ & $<0.00 \mathrm{I}^{\mathrm{a}}$ \\
\hline \multicolumn{4}{|l|}{ Pack-years } \\
\hline Mean \pm SD & $58.9 \pm 31.9$ & $75.9 \pm 23.9$ & $0.003^{\mathrm{a}}$ \\
\hline \multicolumn{4}{|l|}{ COPD } \\
\hline Nolyes & $68 / 54$ & $21 / 18$ & 0.836 \\
\hline \multicolumn{4}{|l|}{ Arterial hypertension } \\
\hline No/yes & $77 / 45$ & $21 / 18$ & 0.302 \\
\hline \multicolumn{4}{|l|}{ Diabetes mellitus } \\
\hline No/yes & $102 / 20$ & $34 / 5$ & 0.592 \\
\hline \multicolumn{4}{|l|}{ Coronary disease } \\
\hline No/yes & $98 / 24$ & $34 / 5$ & 0.332 \\
\hline \multicolumn{4}{|l|}{ Hypothyroidism } \\
\hline No/yes & $118 / 4$ & $36 / 3$ & $0.36 \mathrm{I}^{\mathrm{b}}$ \\
\hline \multicolumn{4}{|l|}{ Gastritis/ulcer } \\
\hline No/yes & $105 / 17$ & $33 / 6$ & 0.822 \\
\hline \multicolumn{4}{|l|}{ Other comorbidity } \\
\hline No/yes & $97 / 25$ & $33 / 6$ & $0.48 I$ \\
\hline \multicolumn{4}{|l|}{ Disease-related variables } \\
\hline \multicolumn{4}{|l|}{ Histotype } \\
\hline Non-differentiated NSCLC & 33 & 16 & $0.586^{\mathrm{b}}$ \\
\hline Squamous & 38 & II & \\
\hline Adenocarcinoma & 48 & 11 & \\
\hline Large cell carcinoma & 3 & 1 & \\
\hline \multicolumn{4}{|l|}{ Location } \\
\hline Central/peripheral & $105 / 17$ & $33 / 6$ & 0.822 \\
\hline \multicolumn{4}{|l|}{ Bronchoscopic findings } \\
\hline Mass & 29 & 7 & 0.151 \\
\hline Infiltration & 78 & 31 & \\
\hline None & 15 & I & \\
\hline \multicolumn{4}{|l|}{ Lung tumor side } \\
\hline Right/left & $62 / 60$ & $22 / 17$ & 0.543 \\
\hline \multicolumn{4}{|l|}{ Lung tumor lobe } \\
\hline Upper & 86 & 27 & 0.657 \\
\hline Middle & 5 & 3 & \\
\hline Inferior & 31 & 9 & \\
\hline Lung tumor size & & & \\
\hline Mean \pm SD & $45.9 \pm 19.3$ & $55.1 \pm 20.1$ & $0.012^{\mathrm{a}}$ \\
\hline Other tumor characteristic & & & \\
\hline Pleural effusion & 48 & II & 0.399 \\
\hline Cavitation & 8 & 4 & \\
\hline None & 66 & 24 & \\
\hline $\mathrm{T}$ classification (brain metas & tases) ${ }^{c}$ & & \\
\hline $\mathrm{T}_{1} / \mathrm{T}_{2}$ & $10 / 37$ & $3 / 18$ & 0.138 \\
\hline $\mathrm{T}_{3} / \mathrm{T}_{4}$ & $22 / 53$ & $2 / 16$ & \\
\hline $\mathrm{N}$ classification (brain metas & stases) $)^{c}$ & & \\
\hline $\mathrm{N}_{0} / \mathrm{N}_{1}$ & $29 / 10$ & $9 / 6$ & 0.550 \\
\hline $\mathrm{N}_{2} / \mathrm{N}_{3}$ & $53 / 30$ & $17 / 7$ & \\
\hline Lung metastasis & & & \\
\hline No/yes & $67 / 55$ & $34 / 5$ & $<0.001$ \\
\hline
\end{tabular}

(Continued)
Table 2 (Continued)

\begin{tabular}{|c|c|c|c|}
\hline \multirow[t]{2}{*}{ Feature } & \multicolumn{2}{|c|}{ Brain metastases } & \multirow[t]{2}{*}{$P \chi^{2}$ test } \\
\hline & No (N) & Yes (N) & \\
\hline \multicolumn{4}{|c|}{ Bone metastasis } \\
\hline No/yes & $70 / 52$ & $32 / 7$ & 0.005 \\
\hline \multicolumn{4}{|c|}{ Liver metastasis } \\
\hline Nolyes & $91 / 31$ & $33 / 6$ & 0.195 \\
\hline \multicolumn{4}{|l|}{ Adrenal } \\
\hline No/yes & $91 / 31$ & $35 / 4$ & 0.046 \\
\hline \multicolumn{4}{|c|}{ Other metastasis } \\
\hline No/yes & $107 / 15$ & $37 / 2$ & 0.205 \\
\hline
\end{tabular}

Notes: ${ }^{2}$ Student's $t$-test; ' ${ }^{\circ}$ isher's exact test; 'TNM (tumor-node-metastasis) classification. ${ }^{21}$

Abbreviations: COPD, chronic obstructive pulmonary disease; NSCLC, non-small cell lung cancer; SD, standard deviation.

\section{$\mathrm{T}$ and $\mathrm{N}$ status}

$\mathrm{T} 4$ initial status was associated with increased risk of BM in a multivariate analysis of 305 patients with localized NSCLC. ${ }^{30}$ The N2 status was found to be predictive of BM by Jacobs et al and by Tang et al. ${ }^{36,37}$

In this study, lung tumor size was correlated with the appearance of $\mathrm{BM}(55.1 \pm 20.1 \mathrm{~cm})$ (Table 2). This finding is in agreement with the study of Mujoomdar et al. ${ }^{31}$ However, no correlation was found with the $\mathrm{T}$ status itself. T status, as well as $\mathrm{N}$ status, has been correlated with BM outbreak in recent studies. ${ }^{30,31}$

As is the case in the study of Shi et al, the authors of this present study found most of the primary tumors to be located in the right lung and in the upper lobes. ${ }^{32}$ These frequent locations of lung tumor did not seem to correlate with the appearance of BM. ${ }^{32}$ Central or peripheral location of primary lung tumor was not found to be correlated to BM, which is in agreement with the study of Mujoomdar et al. ${ }^{31}$

\section{M status}

Previous studies speculate that the spread of lung cancer to the thoracic lymphatic system and to the brain could also relate to the presence of distant metastatic disease in other organs. ${ }^{31}$ So far, no study has confirmed this hypothesis. On the contrary, in this present study, appearance of BM was correlated with the absence of metastases in other organs, like lung, bone, and adrenal glands. Except adrenal metastases ${ }^{27}$ synchronous metastases in other organs have not been correlated with median survival, probably as a result of already poor prognosis of the $\mathrm{BM}^{26}$

\section{Tobacco consumption}

Smoking status has already been correlated with poor prognosis and shorter overall survival in lung cancer patients, ${ }^{18}$ but no correlation was found with BM. In this study's cohort, high tobacco consumption $(75.9 \pm 23.9$ packyears) was correlated with the outbreak of BM. 
Table 3 Univariate analysis of brain metastases side

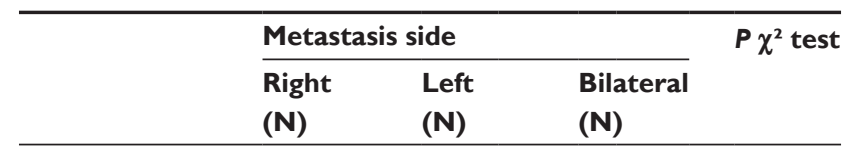

\begin{tabular}{|c|c|c|c|c|}
\hline \multicolumn{5}{|c|}{ Patient-related variables } \\
\hline \multicolumn{5}{|l|}{ Sex } \\
\hline Male/female & $\mid 1 / 1$ & $9 / 0$ & $15 / 3$ & 0.546 \\
\hline \multicolumn{5}{|l|}{ Age } \\
\hline Mean \pm SD & $57.7 \pm 8.3$ & $62.6 \pm 9.9$ & $61.9 \pm 8.7$ & $0.349^{\mathrm{a}}$ \\
\hline \multicolumn{5}{|l|}{ Pack-years } \\
\hline Mean \pm SD & $80.8 \pm 20.2$ & $84.0 \pm 19.6$ & $68.6 \pm 26.8$ & $0.202^{\mathrm{a}}$ \\
\hline \multicolumn{5}{|l|}{ COPD } \\
\hline No/yes & $6 / 6$ & $5 / 4$ & $10 / 8$ & 1.000 \\
\hline \multicolumn{5}{|l|}{ Arterial hypertension } \\
\hline No/yes & $10 / 2$ & $4 / 5$ & $7 / 11$ & 0.050 \\
\hline \multicolumn{5}{|l|}{ Coronary disease } \\
\hline No/yes & $12 / 0$ & $9 / 0$ & $13 / 5$ & 0.054 \\
\hline \multicolumn{5}{|l|}{ Diabetes mellitus } \\
\hline No/yes & $11 / 1$ & $9 / 0$ & $14 / 4$ & 0.406 \\
\hline \multicolumn{5}{|l|}{ Gastritis/ulcer } \\
\hline No/yes & $12 / 0$ & $7 / 2$ & $|7 /|$ & 0.216 \\
\hline \multicolumn{5}{|l|}{ Hypothyroidism } \\
\hline Nolyes & $12 / 0$ & $6 / 3$ & $15 / 3$ & 0.063 \\
\hline \multicolumn{5}{|l|}{ Other comorbidity } \\
\hline No/yes & $11 / 1$ & $7 / 2$ & $15 / 3$ & 0.740 \\
\hline \multicolumn{5}{|c|}{ Disease-related variables } \\
\hline \multicolumn{5}{|l|}{ Histotype } \\
\hline Non-differentiated & 6 & 2 & 7 & 0.194 \\
\hline \multicolumn{5}{|l|}{ NSCLC } \\
\hline Squamous & 2 & 4 & 5 & \\
\hline Adenocarcinoma & 3 & 3 & 6 & \\
\hline Large cell & I & 0 & 0 & \\
\hline \multicolumn{5}{|l|}{ carcinoma } \\
\hline \multicolumn{5}{|l|}{ Location } \\
\hline Central/peripheral & $10 / 2$ & $8 / 1$ & $15 / 3$ & 1.000 \\
\hline \multicolumn{5}{|c|}{ Diagnosis to brain metastases time (weeks) } \\
\hline Median (IR) & $18(4-40)$ & $0(0-26)$ & $14(0-36)$ & $0.632^{\mathrm{b}}$ \\
\hline
\end{tabular}

\section{NSCLC histological subtype}

In previous studies, non-squamous lung cancer, mainly lung adenocarcinoma, showed higher prevalence of BM development. ${ }^{30-32}$ In this study, no correlation was found between NSCLC histotype and BM appearance. This discordance is probably a result of the small number of allocated groups and the relatively large number of unspecified NSCLC tumors in the present study.

\section{$\mathrm{PCl}$}

Prophylactic cranial irradiation (PCI) has been demonstrated to reduce the incidence or delay the onset of $\mathrm{BM}$ in patients with locally advanced NSCLC after initial treatment..$^{3,7,9-16}$ Thus, identification of risk population
Table 4 Univariate analysis of brain metastases lobes

\begin{tabular}{|c|c|c|c|}
\hline & \multicolumn{2}{|c|}{ Metastasis lobe } & \multirow{2}{*}{$\begin{array}{l}\text { P Fisher's } \\
\text { exact test }\end{array}$} \\
\hline & $\begin{array}{l}\text { I lobe } \\
\text { (N) }\end{array}$ & $\begin{array}{l}\geq 2 \text { lobes } \\
\text { (N) }\end{array}$ & \\
\hline \multicolumn{4}{|c|}{ Patient-related variables } \\
\hline \multicolumn{4}{|l|}{ Sex } \\
\hline Male/female & $19 / 2$ & $16 / 2$ & 1.000 \\
\hline \multicolumn{4}{|l|}{ Age } \\
\hline Mean \pm SD & $61.0 \pm 9.5$ & $60.6 \pm 8.3$ & $0.891^{\mathrm{a}}$ \\
\hline \multicolumn{4}{|l|}{ Pack-years } \\
\hline Mean \pm SD & $79.1 \pm 19.8$ & $72.2 \pm 28.0$ & $0.377^{\mathrm{a}}$ \\
\hline \multicolumn{4}{|l|}{ COPD } \\
\hline Nolyes & $12 / 9$ & $9 / 9$ & $0.656^{\mathrm{b}}$ \\
\hline \multicolumn{4}{|l|}{ Arterial hypertension } \\
\hline No/yes & $13 / 8$ & $8 / 10$ & $0.276^{\mathrm{b}}$ \\
\hline \multicolumn{4}{|l|}{ Diabetes mellitus } \\
\hline No/yes & $21 / 0$ & $13 / 5$ & 0.015 \\
\hline \multicolumn{4}{|l|}{ Coronary disease } \\
\hline Nolyes & $20 / 1$ & $14 / 4$ & 0.104 \\
\hline \multicolumn{4}{|l|}{ Hypothyroidism } \\
\hline No/yes & $19 / 2$ & $|7 /|$ & 1.000 \\
\hline \multicolumn{4}{|l|}{ Gastritis/ulcer } \\
\hline No/yes & $18 / 3$ & $15 / 3$ & 1.000 \\
\hline \multicolumn{4}{|l|}{ Other comorbidity } \\
\hline No/yes & $17 / 4$ & $16 / 2$ & 0.667 \\
\hline \multicolumn{4}{|c|}{ Disease-related variables } \\
\hline \multicolumn{4}{|c|}{ Histotype } \\
\hline Non-differentiated & 7 & 8 & 0.088 \\
\hline \multicolumn{4}{|l|}{ NSCLC } \\
\hline Squamous & 5 & 6 & \\
\hline Adenocarcinoma & 8 & 4 & \\
\hline Large cell carcinoma & 1 & 0 & \\
\hline \multicolumn{4}{|l|}{ Location } \\
\hline Central/peripheral & $17 / 4$ & $16 / 2$ & 0.667 \\
\hline \multicolumn{4}{|c|}{ Diagnosis to brain metastases time (weeks) } \\
\hline Median (IR) & $17(0-32)$ & $8(0-36)$ & $0.922^{c}$ \\
\hline
\end{tabular}

Notes: a'Student's t-test; 'Pearson's $\chi^{2}$ test; 'Mann-Whitney test.

Abbreviations: COPD, chronic obstructive pulmonary disease; IR, interquartile range; NSCLC, non-small cell lung cancer; SD, standard deviation.

for BM development is pertinent. Specific phenotypes of patients at higher risk for BM development could serve as candidates of PCI and could allow early intervention, which seems more promising than the palliative approach.

\section{Limitations}

The patients in this current study were treated with sequential rather than concurrent chemoradiotherapy despite the current treatment guidelines. This limitation of the study is due to the lack of a radiotherapy department in the "Sotiria" Chest Diseases Hospital.

The pathologic data lack molecular markers, which could be related to the overall survival as is the case in many 
Table 5 Correlation of brain metastases with patient- and disease-related features (multivariate analysis)

\begin{tabular}{lllll}
\hline Variable & Odds ratio & $\mathbf{9 5 \%}$ & $\mathbf{C l}$ & $\boldsymbol{P}$ \\
\hline Age & $0.9 \mathrm{I}$ & 0.87 & 0.96 & $<0.00 \mathrm{I}$ \\
Pack-years & $\mathrm{I} .02$ & $\mathrm{I} .0 \mathrm{I}$ & $\mathrm{I} .03$ & 0.006 \\
Lung metastasis & & & & \\
No & $1.00^{\mathrm{a}}$ & & & \\
Yes & 0.24 & 0.08 & 0.69 & 0.008 \\
Bone metastasis & & & & \\
No & $1.00^{\mathrm{a}}$ & & & \\
Yes & 0.30 & $0.1 \mathrm{I}$ & $0.8 \mathrm{I}$ & 0.018 \\
\hline
\end{tabular}

Note: aRepresents referral class.

recent studies. In fact, during the study period, molecular data were not available.

\section{Implications}

This study records the deleterious effect of BMs on NSCLC patient survival, enriches the high risk profile with more features, and contributes to the discussion of pathophysiologic mechanisms underlying the brain involvement in NSCLC. More studies are needed in order to elucidate these issues.

\section{Conclusion}

Younger NSCLC patients with high tobacco consumption, large tumor size, and absence of other metastases (lung, bones, adrenal metastases) are at high risk of BM appearance during the course of NSCLC and may be candidates for PCI early in the course of their disease. Apart from genome-based studies, phenotype-based studies may contribute to future lung cancer therapy.

\section{Disclosure}

The authors report no conflicts of interest in this work.

\section{References}

1. Ferlay J, Autier P, Boniol M, Heanue M, Colombet M, Boyle P. Estimates of the cancer incidence and mortality in Europe in 2006. Ann Oncol. 2007; 18:581-592.

2. Walker S. Updates in non-small cell lung cancer. Clin J Oncol Nurs. 2008;2:587-596.

3. Albain KS, Rusch VW, Crowley JJ, et al. Concurrent cisplatin/etoposide plus chest radiotherapy followed by surgery for stages IIIA (N2) and IIIB non-small-cell lung cancer: Mature results of Southwest Oncology Group Phase II study 8805. J Clin Oncol. 1995;13:1880-1892.

4. Andre F, Grunenwald D, Pujol JL, et al. Patterns of relapse of N2 nonsmall-cell lung carcinoma patients treated with preoperative chemotherapy: Should prophylactic cranial irradiation be reconsidered? Cancer. 2001;91:2394-2400.

5. Cox JD, Scott CB, Byhardt RW, et al. Addition of chemotherapy to radiation therapy alters failure patterns by cell type within non-small cell carcinoma of lung (NSCCL): Analysis of Radiation Therapy Oncology Group (RTOG) trials. Int J Radiat Oncol Biol Phys. 1999;43:505-509.

6. Cooper JD, Silverman S, Clement JA. Prophylactic cranial irradiation for lung cancer patients at high risk for development of cerebral metastasis: Results of a prospective randomized trial conducted by the Radiation Therapy Oncology Group. Int J Radiat Oncol Biol Phys. 1991;21:637-643.
7. Stuschke M, Eberhardt W, Pottgen C, et al. Prophylactic cranial irradiation in locally advanced nonsmall-cell lung cancer after multimodality treatment: Long-term follow-up and investigations of late neuropsychologic effects. J Clin Oncol. 1999;17:2700-2709.

8. Andre F, Grunenwald D, Pujol JL, et al. Patterns of relapse of N2 nonsmall-cell lung carcinoma patients treated with preoperative chemotherapy: Should prophylactic cranial irradiation be reconsidered? Cancer. 2001;91:2394-2400.

9. Strauss GM, Herndon JE, Sherman DD, et al. Neoadjuvant chemotherapy and radiotherapy followed by surgery in stage IIIA non-small cell carcinoma of the lung: Report of a Cancer and Leukemia Group B phase II study. J Clin Oncol. 1992;10:237-1244.

10. Rusch VW, Griffin BR, Livingston RB. The role of prophylactic cranial irradiation in regionally advanced non-small cell lung cancer. A Southwest Oncology Group Study. J Thorac Cardiovasc Surg. 1989;98:535-539.

11. Skarin A, Jochelson M, Sheldon T, et al. Neoadjuvant chemotherapy in marginally resectable stage III M0 non-small cell lung cancer: Longterm follow-up in 41 patients. J Surg Oncol. 1989;40:266-274.

12. Russell AH, Pajak TE, Selim HM, et al. Prophylactic cranial irradiation for lung cancer patients at high risk for development of cerebral metastasis: Results of a prospective randomized trial conducted by the Radiation Therapy Oncology Group. Int J Radiat Oncol Biol Phys. 1991;21:637-643.

13. Umsawasdi T, Valdivieso M, Chen TT, et al. Role of elective brain irradiation during combined chemoradiotherapy for limited disease non-small cell lung cancer. J Neuro Oncol. 1984;2:253-259.

14. Cox JD, Stanley K, Petrovich Z, Paig C, Yesner R. Cranial irradiation in cancer of the lung of all cell types. JAMA. 1981;245:469-472.

15. Pöttgen C, Eberhardt W, Grannass A, et al. Prophylactic cranial irradiation in operable stage IIIA non-small-cell lung cancer treated with neoadjuvant chemoradiotherapy: Results from a German multicenter trial. J Clin Oncol. 2007;25:4987-4992.

16. Yavuz AA, Topkan E, Onal C, Yavuz MN. Prophylactic cranial irradiation in locally advanced non-small cell lung cancer: Outcome of recursive partitioning analysis group I patients. J Exp Clin Cancer Res. 2008;27:80.

17. Robnett TJ, Machtay M, Stevenson JP, Algazy KM, Hahn SM. Factors affecting the risk of brain metastases after definitive chemoradiation for locally advanced non-small-cell lung carcinoma. J Clin Oncol. 2001;19:1344-1349.

18. Law A, Karp DD, Dipetrillo T, Daly BT. Emergence of increased cerebral metastasis after high-dose preoperative radiotherapy with chemotherapy in patients with locally advanced non-small cell lung carcinoma. Cancer. 2001;92:160-164.

19. Ceresoli GL, Reni M, Chiesa G, et al. Brain metastases in locally advanced nonsmall cell lung carcinoma after multimodality treatment: Risk factors analysis. Cancer. 2002;95:605-612.

20. Carolan H, Sun AY, Bezjak A, et al. Does the incidence and outcome of brain metastases in locally advanced non-small cell lung cancer justify prophylactic cranial irradiation or early detection? Lung Cancer. 2005;49:109-115.

21. Sobin LH, Wittekind C; and the International Union Against Cancer (UICC), editors. TNM Classification of Malignant Tumors. 6th ed. New York, NY: Wiley-Liss; 2002:99-103.

22. Alberts M. Lung Cancer Guidelines. Chest. 2003;123:1-2.

23. Alberts M. Diagnosis and management of lung cancer. Executive summary. Chest. 2007;132:1-19.

24. Addeo R, Caraglia M, Faiola V, et al. Concomitant treatment of brain metastasis with whole brain radiotherapy [WBRT] and temozolomide [TMZ] is active and improves quality of life. BMC. 2007;7:18.

25. Ma S, Xu Y, Deng Q, Yu X. Treatment of brain metastasis from nonsmall cell lung cancer with whole brain radiotherapy and Gefitinib in a Chinese population. Lung Cancer. 2009;65:198-203.

26. Jacot W, Quantin X, Boher JM, et al. Brain metastases at the time of presentation of non-small cell lung cancer: A multi-centric AERIO* analysis of prognostic factors. Br J Cancer. 2001;84:903-909. 
27. Penel N, Brichet A, Prevost B, et al. Prognostic factors for synchronous brain metastases from lung cancer. Lung Cancer. 2001;33:143-154.

28. Arrieta O, Saavedra-Perez D, Kuri R, et al. Brain metastasis development and poor survival associated with carcinoembryonic antigen (CEA) level in advanced non-small cell cancer: A prospective analysis. BMC Cancer. 2009;9:119.

29. Robnett T, Machtay M, Stevenson J, et al. Factors affecting the risk of brain metastases after definitive chemoradiation for locally advanced non-small-cell lung carcinoma. J Clin Oncol. 2001;19:1344-1349.

30. Bajard A, Westeel V, Dubiez A. Multivariate analysis of factors predictive of brain metastases in localized non-small cell lung carcinoma. Lung Cancer. 2004;45:317-323.

31. Mujoomdar A, Austin J, Malhota R, et al. Clinical predictors of metastatic disease to the brain from non-small cell lung carcinoma: Primary tumor size, cell type, and lymph node metastases. Radiology. 2007;242:882-888.

32. Shi A, Digumarthy S, Temel J, Halpern EF, Kuester LB, Aquino SL. Does initial staging or tumor histology better identify asymptomatic brain metastases in patients with non-small cell lung caner? J Thorac Oncol. 2006;1:205-210.
33. Ceresoli GL, Reni M, Chiesa G, et al. Brain metastases in locally advanced non-small cell lung carcinoma after multimodality treatment: Risk factors analysis. Cancer. 2002;95:605-612.

34. Schouten LJ, Rutten J, Huveneers HA, Twinjstra A. Incidence of brain metastases in a cohort of patients with carcinoma of the breast, colon, kidney, and lung and melanoma. Cancer. 2002;94:2698-2705.

35 . Gore E. Brain metastases in very young patients with lung cancer are still brain metastases. Onkologie. 2008;31:297-268.

36. Jacobs RH, Awan A, Bitran JD, et al. Prophylactic cranial irradiation in adenocarcinoma of the lung: A possible role. Cancer. 1987;59: 2016-2019.

37. Tang SG, Lin FJ, Leung VM. Impact of cranial irradiation in adenocarcinoma of the lung. J Formos Med Assoc. 1993;92:413-419.

\section{Publish your work in this journal}

Cancer Management and Research is an international, peer-reviewed open access journal focusing on cancer research and the optimal use of preventative and integrated treatment interventions to achieve improved outcomes, enhanced survival and quality of life for the cancer patient. The journal welcomes original research, clinical \& epidemiological studies, reviews \& evaluations, guidelines, expert opinion \& commentary, case reports \& extended reports. The manuscript management system is completely online and includes a very quick and fair peerreview system, which is all easy to use. Visit http://www.dovepress.com/ testimonials.php to read real quotes from published authors. 